\title{
EFFECTS OF TURMERIC AND ITS ACTIVE PRINCIPLE, CURCUMIN, ON BLEOMYCIN- INDUCED CHROMOSOME ABERRATIONS IN CHINESE HAMSTER OVARY CELLS
}

\author{
Maria Cristina P. Araújo ${ }^{1,2}$, Francisca da Luz Dias ${ }^{2}$, Sergio N. Kronka ${ }^{3}$ and Catarina S. Takahashi ${ }^{2,4}$
}

\begin{abstract}
Naturally occurring antioxidants have been extensively studied for their capacity to protect organisms and cells from oxidative damage. Many plant constituents including turmeric and curcumin appear to be potent antimutagens and antioxidants. The effects of turmeric and curcumin on chromosomal aberration frequencies induced by the radiomimetic agent bleomycin (BLM) were investigated in Chinese hamster ovary (CHO) cells. Three concentrations of each drug, turmeric $(100,250$ and $500 \mu \mathrm{g} /$ $\mathrm{ml})$ and curcumin $(2.5,5$ and $10 \mu \mathrm{g} / \mathrm{ml})$, were combined with BLM $(10 \mu \mathrm{g} / \mathrm{ml})$ in CHO cells treated during the $\mathrm{G}_{1} / \mathrm{S}, \mathrm{S}$ or $\mathrm{G}_{2} / \mathrm{S}$ phases of the cell cycle. Neither turmeric nor curcumin prevented BLM-induced chromosomal damage in any phases of the cell cycle. Conversely, a potentiation of the clastogenicity of BLM by curcumin was clearly observed in cells treated during the $\mathrm{S}$ and $\mathrm{G}_{2} / \mathrm{S}$ phases. Curcumin was also clastogenic by itself at $10 \mu \mathrm{g} / \mathrm{ml}$ in two protocols used. However, the exact mechanism by which curcumin produced clastogenic and potentiating effects remains unknown.
\end{abstract}

\section{INTRODUCTION}

Recently a variety of compounds that possess antimutagenic properties has been detected in vegetables and spices, and evidence is accumulating that their dietary intake decreases the risk of cancer and other malignant diseases in human (Kada et al., 1986). Antioxidant compounds, especially phenols such as gallic acid, tannins, curcumin, ellagic acid and eugenol, are of considerable interest from the viewpoint of dietary antioxidant supplementation (Halliwell, 1994).

Turmeric, a spice obtained from the rhizome of Curcuma longa Linn (Zingiberaceae), has been regularly used for its coloring, flavoring and medicinal properties (Ammon and Wahl, 1991). Studies suggest that turmeric is a potent antimutagenic in vivo against carcinogens such as benzo[a]pyrene and methylcholanthrene (Polasa et al., 1991), and it is effective in inhibiting the formation and excretion of urinary mutagens in smokers (Polasa et al., 1992).

Curcumin, the active principle of turmeric, is commonly used as a coloring agent in foods, drugs and cosmetics, and has a wide range of effects. Curcumin is known to act as an antioxidant, antimutagen and anticarcinogen (Sharma, 1976; Kunchandy and Rao, 1990; Nagabhushan and Bhide, 1992; Rao et al., 1995; Anto et al., 1996). Curcumin also has therapeutic properties for some human diseases (Srimal and Dhawan, 1973; Srivastava et al., 1985).

\footnotetext{
${ }^{1}$ Departamento de Genética, Universidade Federal de Pernambuco, PE, Brasil. ${ }^{2}$ Departamento de Genética, Faculdade de Medicina de Ribeirão Preto, USP, Av. Bandeirantes, 3900, 14049-900 Ribeirão Preto, SP, Brasil. Send correspondence to M.C.P.A.

${ }^{3}$ Departamento de Ciências Exatas, UNESP, Jaboticabal, SP, Brasil.

${ }^{4}$ Departamento Biologia, Faculdade de Filosofia, Ciências e Letras de Ribeirão Preto, USP, Ribeirão Preto, SP, Brasil.
}

Bleomycin (BLM) is an antibiotic and radiomimetic glycopeptide that is routinely used in cancer chemotherapy as an antineoplastic agent. BLM is mutagenic in diverse genetic assays (Povirk and Austin, 1991) and is thought to exert its genotoxic effects through free radical production and the induction of oxidative damage to DNA (Lown and Sim, 1977; Cunningham et al., 1984; Sikic, 1986).

The aim of the present study was to investigate the action of the antioxidants turmeric and curcumin on chromosomal damage induced by the oxidative agent BLM, by determining their effect on the frequency of BLM-induced chromosomal aberrations in Chinese hamster ovary $(\mathrm{CHO})$ cells.

\section{MATERIAL AND METHODS}

\section{Chemicals}

Turmeric was donated by Quest International Company (Brazil), curcumin (diferuloylmethane; C.I. 75300) was purchased from Sigma Chemical Co. (USA), and bleomycin sulfate was obtained from Hospital das Clínicas, USP, Brazil (Blenoxane ${ }^{\circledR}$; Bristol-Myers Squibb, Brazil). Turmeric and BLM were dissolved in distilled water and curcumin was dissolved in dimethyl sulfoxide (DMSO; Sigma), just before each treatment. The final concentration of DMSO in the medium was $0.5 \%$. Concentrations of BLM $(10 \mu \mathrm{g} / \mathrm{ml})$, turmeric $(100,250$ and $500 \mu \mathrm{g} / \mathrm{ml})$ and curcumin $(2.5,5$ and $10 \mu \mathrm{g} / \mathrm{ml})$ were chosen based on results obtained in pilot experiments (data not shown).

\section{Cell culture and treatments}

Chinese hamster ovary cells (CHO-9 cell line) were kindly supplied by Prof. A.T. Natarajan (University of Leiden, The Netherlands). Cells were maintained as monolayers growing at $37^{\circ} \mathrm{C}$ in $25-\mathrm{cm}^{2}$ flasks (Corning) containing HAM-F10 (Sigma) plus DMEM (Dulbecco's modi- 
fied Eagle's medium; Sigma), supplemented with $10 \%$ newborn bovine serum (Cultilab), antibiotics $(0.1 \mathrm{mg} / \mathrm{ml}$ streptomycin and $0.06 \mathrm{mg} / \mathrm{ml}$ penicillin), and $2.38 \mathrm{mg} / \mathrm{ml}$ HEPES (Sigma). Cells were subcultured two or three times a week. The experiments were performed with cells at six to 12 passages.

Cells were seeded at a density of $10^{6}$ cells/flask and then treated with either turmeric or curcumin, that remained in the culture until cell harvesting, $1 \mathrm{~h}$ before BLM addition. BLM treatment lasted $30 \mathrm{~min}$. After this, cells were washed twice with PBS and refed complete medium plus either turmeric or curcumin. Exponentially growing $\mathrm{CHO}$ cells have a doubling time of 12-14 h (Preston et al. 1987; Cozzi et al., 1993). In this work, total culture time was $14 \mathrm{~h}$. Cells were harvested three, eight and $12 \mathrm{~h}$ after initiation of BLM treatment. According to Preston et al. (1981), cells fixed three, eight and $12 \mathrm{~h}$ after the beginning of treatment are, respectively, in the late $G_{2} / S$, middle $S$ and early $G_{1} / S$ phases of the cell cycle at the moment they are treated. Untreated controls were handled identically, with the same changes in medium. Colcemide (100 $\mu \mathrm{l}$ at a concentration of $5 \mu \mathrm{g} / \mathrm{ml}$ ) was added to the culture medium $2 \mathrm{~h}$ before harvesting. Each experiment was repeated three times.

Cells were harvested by the method of Moorhead et al. (1960), with modifications (1\% sodium citrate hypotonic solution, methanol/acetic acid 3:1 fixative). The airdried chromosome preparations were stained with $3 \%$ Giemsa, diluted in phosphate buffer. Only well-spread metaphases presenting $21 \pm 1$ chromosomes were analyzed. Three hundred metaphases (100 in each experiment) were analyzed per treatment in order to determine the frequencies of chromosomal aberrations (blind test). The mitotic index was obtained by counting the number of mitotic cells in 3,000 cells per treatment (1,000 in each experiment).

\section{Statistical analysis}

Data concerning number of abnormal metaphases and total number of chromosomal aberrations, including gaps, and mitotic index were statistically analyzed by analysis of variance, with calculations of the F-statistic and respective $P$ values. In all cases in which $P<0.05$ the mean values of each treatment were compared by the Tukey test, with calculation of the minimum significant difference for $\mathrm{P}=0.05$.

\section{RESULTS}

Frequencies of abnormal metaphases, chromosomal aberrations and mitotic indices in $\mathrm{CHO}$ cells treated with turmeric combined or not with BLM during $\mathrm{G}_{1} / \mathrm{S}, \mathrm{S}$ or $\mathrm{G}_{2} /$ $\mathrm{S}$ phases of the cell cycle were determined (Tables I, II and III). Mitotic indices observed in cultures treated with turmeric were not significantly different from those found in untreated controls, except when $500 \mu \mathrm{g} / \mathrm{ml}$ turmeric was associated with BLM at the $\mathrm{G}_{1} / \mathrm{S}$ phase (Table I). Turmeric was not clastogenic in any protocol tested. Although a statistically significant difference was not detected when compared with BLM alone, there was a tendency for the highest concentration of turmeric combined with BLM to increase the frequency of abnormal metaphases and chromosomal aberrations in cells treated at $\mathrm{G}_{1} / \mathrm{S}$ phase. On the other hand, turmeric did not show any significant effect on bleomycin-induced aberrations.

A 30-min pulse treatment with BLM at $10 \mu \mathrm{g} / \mathrm{ml}$ to $\mathrm{CHO}$ cells produced a marked induction of chromosome aberrations. BLM at this concentration was also used as a clastogenic agent by other authors (Salvadori et al., 1994; Anderson et al., 1994). In this paper, the main aberration types after BLM exposure at $\mathrm{G}_{1} / \mathrm{S}$ were isochromatid breaks and dicentrics, and in the case of treatment

Table I - Distribution of the different types of chromosomal aberrations in 300 cells analyzed per group of treatment and mitotic index ${ }^{\psi}(\mathrm{MI})$ observed in $\mathrm{CHO}$ cells after treatment with turmeric $(13 \mathrm{~h})$ and/or bleomycin (BLM, $10 \mu \mathrm{g} / \mathrm{ml})$ during $\mathrm{G}_{1} / \mathrm{S}$ phase.

\begin{tabular}{|c|c|c|c|c|c|c|c|c|c|c|}
\hline \multirow{3}{*}{\multicolumn{2}{|c|}{$\begin{array}{l}\text { Treatment } \\
(\mu \mathrm{g} / \mathrm{ml})\end{array}$}} & \multirow{3}{*}{$\begin{array}{l}\text { MI } \\
(\%)\end{array}$} & \multirow{3}{*}{$\mathrm{AM}$} & \multicolumn{6}{|c|}{ Aberrations } & \multirow{3}{*}{ Total } \\
\hline & & & & \multicolumn{3}{|c|}{ Chromatid type } & \multicolumn{3}{|c|}{ Chromosome type } & \\
\hline & & & & gaps & breaks & exch & breaks & dic & rings & \\
\hline \multicolumn{2}{|c|}{ Untreated control } & 12.6 & 8 & 3 & 3 & 0 & 3 & 0 & 0 & 9 \\
\hline \multirow[t]{3}{*}{ Turmeric } & 100 & 11.5 & 5 & 3 & 0 & 0 & 5 & 0 & 0 & 8 \\
\hline & 250 & 11.4 & 14 & 14 & 2 & 0 & 3 & 1 & 1 & 21 \\
\hline & 500 & 10.2 & 9 & 4 & 2 & 2 & 1 & 0 & 0 & 9 \\
\hline \multirow{4}{*}{$\begin{array}{l}\text { BLM } \\
\text { Turmeric }\end{array}$} & & 10.3 & $63 *$ & 9 & 20 & 21 & 61 & 28 & 5 & $144 *$ \\
\hline & $100+$ BLM & 10.4 & $77 *$ & 9 & 13 & 14 & 74 & 39 & 10 & $159 *$ \\
\hline & $250+$ BLM & 9.9 & $99 *$ & 12 & 22 & 45 & 67 & 37 & 11 & $194 *$ \\
\hline & $500+$ BLM & $4.5^{*}$ & $87 *$ & 24 & 26 & 36 & 59 & 51 & 14 & $210^{*}$ \\
\hline
\end{tabular}

$\psi_{3000}$ cells were counted per treatment. $\mathrm{AM}=$ Abnormal metaphases; dic $=$ dicentrics; exch $=$ exchange (including: triradials, quadriradials, complex exchanges and sister union). *Statistically different when compared with untreated control. 
Table II - Distribution of the different types of chromosomal aberrations in 300 cells analyzed per group of treatment and mitotic index ${ }^{\psi}(\mathrm{MI})$ observed in $\mathrm{CHO}$ cells after treatment with turmeric $(9 \mathrm{~h})$ and/or bleomycin (BLM, $10 \mu \mathrm{g} / \mathrm{ml}$ ) during $\mathrm{S}$ phase.

\begin{tabular}{|c|c|c|c|c|c|c|c|c|c|c|}
\hline \multirow{3}{*}{\multicolumn{2}{|c|}{$\begin{array}{l}\text { Treatment } \\
(\mu \mathrm{g} / \mathrm{ml})\end{array}$}} & \multirow{3}{*}{$\begin{array}{l}\text { MI } \\
(\%)\end{array}$} & \multirow{3}{*}{$\mathrm{AM}$} & \multicolumn{6}{|c|}{ Aberrations } & \multirow{3}{*}{ Total } \\
\hline & & & & \multicolumn{3}{|c|}{ Chromatid type } & \multicolumn{3}{|c|}{ Chromosome type } & \\
\hline & & & & gaps & breaks & exch & breaks & dic & rings & \\
\hline \multicolumn{2}{|c|}{ Untreated control } & 16.8 & 15 & 4 & 4 & 3 & 0 & 4 & 0 & 15 \\
\hline \multirow[t]{3}{*}{ Turmeric } & 100 & 11.9 & 14 & 4 & 5 & 2 & 1 & 3 & 0 & 15 \\
\hline & 250 & 11.5 & 16 & 4 & 7 & 2 & 1 & 4 & 0 & 18 \\
\hline & 500 & 17.3 & 12 & 3 & 4 & 2 & 2 & 2 & 0 & 13 \\
\hline \multirow{4}{*}{$\begin{array}{l}\text { BLM } \\
\text { Turmeric }\end{array}$} & & 10.6 & $68^{*}$ & 9 & 23 & 52 & 15 & 7 & 2 & $108^{*}$ \\
\hline & $100+$ BLM & 9.6 & $64^{*}$ & 7 & 23 & 48 & 16 & 7 & 5 & $106^{*}$ \\
\hline & $250+$ BLM & 11.3 & $64^{*}$ & 13 & 33 & 46 & 10 & 6 & 4 & $112^{*}$ \\
\hline & $500+$ BLM & 7.2 & $71^{*}$ & 10 & 40 & 49 & 8 & 9 & 2 & $118^{*}$ \\
\hline
\end{tabular}

For symbols and abbreviations see Table I.

Table III - Distribution of the different types of chromosomal aberrations in 300 cells analyzed per group of treatment and mitotic index ${ }^{\psi}(\mathrm{MI})$ observed in $\mathrm{CHO}$ cells after treatment with turmeric $(4 \mathrm{~h})$ and/or bleomycin (BLM, $10 \mu \mathrm{g} / \mathrm{ml}$ ) during $\mathrm{G}_{2} / \mathrm{S}$ phase.

\begin{tabular}{|c|c|c|c|c|c|c|c|c|c|c|}
\hline \multirow{3}{*}{\multicolumn{2}{|c|}{$\begin{array}{l}\text { Treatment } \\
(\mu \mathrm{g} / \mathrm{ml})\end{array}$}} & \multirow{3}{*}{$\begin{array}{l}\text { MI } \\
(\%)\end{array}$} & \multirow{3}{*}{$\mathrm{AM}$} & \multicolumn{6}{|c|}{ Aberrations } & \multirow{3}{*}{ Total } \\
\hline & & & & \multicolumn{3}{|c|}{ Chromatid type } & \multicolumn{3}{|c|}{ Chromosome type } & \\
\hline & & & & gaps & breaks & exch & breaks & dic & rings & \\
\hline \multicolumn{2}{|c|}{ Untreated control } & 13.8 & 4 & 1 & 1 & 0 & 1 & 2 & 0 & 5 \\
\hline \multirow[t]{3}{*}{ Turmeric } & 100 & 11.1 & 13 & 1 & 6 & 0 & 3 & 3 & 1 & 14 \\
\hline & 250 & 13.1 & 11 & 5 & 2 & 0 & 1 & 4 & 0 & 12 \\
\hline & 500 & 14.8 & 7 & 2 & 2 & 0 & 0 & 2 & 1 & 7 \\
\hline \multirow{4}{*}{$\begin{array}{l}\text { BLM } \\
\text { Turmeric }\end{array}$} & & 5.3 & $68^{*}$ & 25 & 55 & 16 & 7 & 3 & 1 & $107 *$ \\
\hline & $100+$ BLM & 7.3 & $68 *$ & 37 & 56 & 16 & 7 & 5 & 0 & $121 *$ \\
\hline & $250+\mathrm{BLM}$ & 9.2 & $57 *$ & 22 & 56 & 8 & 7 & 3 & 2 & $98 *$ \\
\hline & $500+\mathrm{BLM}$ & 6.2 & $60 *$ & 32 & 40 & 13 & 4 & 4 & 1 & $94 *$ \\
\hline
\end{tabular}

For symbols and abbreviations see Table I.

at $\mathrm{S}$ and $\mathrm{G}_{2} / \mathrm{S}$ phases, chromatid breaks, gaps and exchanges were the most frequent.

The effects of curcumin on the frequencies of abnormal metaphases, chromosomal aberrations and mitotic indices induced by BLM in cells treated during $\mathrm{G}_{1} / \mathrm{S}, \mathrm{S}$ or $\mathrm{G}_{2} / \mathrm{S}$ phases were determined (Tables IV, V and VI). Curcumin at $10 \mu \mathrm{g} / \mathrm{ml}$ was clastogenic but not cytotoxic. The chromosomal damage induced by $10 \mu \mathrm{g} / \mathrm{ml}$ curcumin was statistically significant when compared with the untreated control, and chromatid breaks and gaps were the most frequent alterations observed (Tables IV and V). A cytotoxic effect was observed when curcumin at 2.5 and $10 \mu \mathrm{g} / \mathrm{ml}$ was combined with BLM at S phase (Table V) and curcumin at $10 \mu \mathrm{g} / \mathrm{ml}$ combined with BLM at $\mathrm{G}_{2} / \mathrm{S}$ phase (Table VI). When compared with BLM alone plus curcumin control, curcumin at 5 and $10 \mu \mathrm{g} / \mathrm{ml}$ potentiated the clastogenicity of BLM at S (Table V) and in all three concentrations tested in $\mathrm{G}_{2} / \mathrm{S}$ (Table VI). These effects were observed for both abnormal metaphases and chromosome aberrations. The number of abnormal metaphases increased
109 and $83 \%$ in cultures treated at S phase by BLM plus curcumin at 5 or $10 \mu \mathrm{g} / \mathrm{ml}$, respectively, and 41, 60 and $115 \%$ in cultures treated at $\mathrm{G}_{2} / \mathrm{S}$ phase by BLM plus curcumin at $2.5,5$ or $10 \mu \mathrm{g} / \mathrm{ml}$, respectively. The total number of chromosome aberrations increased 239 and 229\% in cultures treated at S phase by BLM plus curcumin at 5 or $10 \mu \mathrm{g} / \mathrm{ml}$, respectively, and 153 and $359 \%$ in cultures treated at $\mathrm{G}_{2} / \mathrm{S}$ by BLM plus curcumin at 5 or $10 \mu \mathrm{g} / \mathrm{ml}$, respectively. These values were calculated by comparing those observed for the association BLM + curcumin with the expected values (sum of the effects caused by each agent alone). The main aberration types observed in cells treated with curcumin combined with BLM, in which a synergistic effect had occurred, were chromatid breaks and gaps.

\section{DISCUSSION}

The CHO cell system has been used to evaluate mutagenesis and antimutagenesis activities of different 
Table IV - Distribution of the different types of chromosomal aberrations in 300 cells analyzed per group of treatment and mitotic index ${ }^{\psi}(\mathrm{MI})$ observed in $\mathrm{CHO}$ cells after treatment with curcumin $(13 \mathrm{~h})$ and/or bleomycin (BLM, $10 \mu \mathrm{g} / \mathrm{ml}$ ) during $\mathrm{G}_{1} / \mathrm{S}$ phase.

\begin{tabular}{|c|c|c|c|c|c|c|c|c|c|}
\hline \multirow{3}{*}{$\begin{array}{l}\text { Treatment } \\
(\mu \mathrm{g} / \mathrm{ml})\end{array}$} & \multirow{3}{*}{$\begin{array}{r}\text { MI } \\
(\%)\end{array}$} & \multicolumn{8}{|c|}{ Aberrations } \\
\hline & & $\mathrm{AM}$ & \multicolumn{3}{|c|}{ Chromatid type } & \multicolumn{3}{|c|}{ Chromosome type } & \multirow[t]{2}{*}{ Total } \\
\hline & & & gaps & breaks & exch & breaks & dic & rings & \\
\hline Untreated control & 14.1 & 5 & 0 & 1 & 0 & 1 & 3 & 0 & 5 \\
\hline DMSO & 13.0 & 14 & 6 & 2 & 0 & 3 & 4 & 0 & 15 \\
\hline Curcumin 2.5 & 18.0 & 17 & 11 & 2 & 1 & 3 & 1 & 0 & 18 \\
\hline 5 & 20.3 & 17 & 10 & 6 & 2 & 0 & 0 & 0 & 18 \\
\hline 10 & 9.9 & $78^{*}$ & 24 & 42 & 13 & 1 & 4 & 1 & $85^{*}$ \\
\hline BLM & 11.5 & $76^{*}$ & 5 & 15 & 24 & 91 & 52 & 12 & $199 *$ \\
\hline Curcumin $2.5+$ BLM & 10.2 & $85^{*}$ & 7 & 16 & 17 & 109 & 65 & 22 & $236^{*}$ \\
\hline $5+\mathrm{BLM}$ & 10.9 & $91^{*}$ & 8 & 29 & 25 & 115 & 58 & 14 & $249^{*}$ \\
\hline $10+$ BLM & 8.2 & $125^{*}$ & 5 & 34 & 126 & 60 & 53 & 14 & $292 *$ \\
\hline
\end{tabular}

For symbols and abbreviations see Table I.

Table V - Distribution of the different types of chromosomal aberrations in 300 cells analyzed per group of treatment and mitotic index ${ }^{\psi}(\mathrm{MI})$ observed in $\mathrm{CHO}$ cells after treatment with curcumin $(9 \mathrm{~h})$ and/or bleomycin (BLM, $10 \mu \mathrm{g} / \mathrm{ml}$ ) during S phase.

\begin{tabular}{|c|c|c|c|c|c|c|c|c|c|}
\hline \multirow{3}{*}{$\begin{array}{l}\text { Treatment } \\
(\mu \mathrm{g} / \mathrm{ml})\end{array}$} & \multirow{3}{*}{$\begin{array}{l}\text { MI } \\
(\%)\end{array}$} & \multirow{3}{*}{$\mathrm{AM}$} & \multicolumn{6}{|c|}{ Aberrations } & \multirow{3}{*}{ Total } \\
\hline & & & \multicolumn{3}{|c|}{ Chromatid type } & \multicolumn{3}{|c|}{ Chromosome type } & \\
\hline & & & gaps & breaks & exch & breaks & dic & rings & \\
\hline Untreated control & 13.9 & 8 & 4 & 4 & 0 & 0 & 0 & 0 & 8 \\
\hline DMSO & 11.6 & 8 & 3 & 2 & 1 & 1 & 1 & 0 & 8 \\
\hline Curcumin 2.5 & 12.4 & 9 & 1 & 4 & 1 & 1 & 2 & 0 & 9 \\
\hline 5 & 9.2 & 15 & 2 & 8 & 3 & 1 & 1 & 0 & 15 \\
\hline 10 & 7.2 & $37 *$ & 10 & 22 & 2 & 2 & 2 & 0 & $38^{*}$ \\
\hline BLM & 11.9 & $48 *$ & 6 & 30 & 20 & 12 & 7 & 0 & $75^{*}$ \\
\hline Curcumin $2.5+$ BLM & $5.7^{*}$ & $57 *$ & 8 & 26 & 57 & 8 & 6 & 2 & $107 *$ \\
\hline $5+\mathrm{BLM}$ & 7.5 & $132 * *$ & 26 & 113 & 142 & 14 & 8 & 2 & $305 * *$ \\
\hline $10+$ BLM & $2.9 *$ & $156^{* * *}$ & 25 & 225 & 97 & 15 & 6 & 4 & $372 * *$ \\
\hline
\end{tabular}

For symbols and abbreviations see Table I. *Statistically different when compared with untreated control. **Statistically different when compared with BLM alone plus curcumin control.

Table VI - Distribution of the different types of chromosomal aberrations in 300 cells analyzed per group of treatment and mitotic index ${ }^{\psi}(\mathrm{MI})$ observed in $\mathrm{CHO}$ cells after treatment with curcumin $(4 \mathrm{~h})$ and/or bleomycin (BLM, $10 \mu \mathrm{g} / \mathrm{ml}$ ) during $\mathrm{G}_{2} / \mathrm{S}$ phase.

\begin{tabular}{|c|c|c|c|c|c|c|c|c|c|}
\hline \multirow{3}{*}{$\begin{array}{l}\text { Treatment } \\
(\mu \mathrm{g} / \mathrm{ml})\end{array}$} & \multirow{3}{*}{$\begin{array}{l}\text { MI } \\
(\%)\end{array}$} & \multirow{3}{*}{$\mathrm{AM}$} & \multicolumn{6}{|c|}{ Aberrations } & \multirow{3}{*}{ Total } \\
\hline & & & \multicolumn{3}{|c|}{ Chromatid type } & \multicolumn{3}{|c|}{ Chromosome type } & \\
\hline & & & gaps & breaks & exch & breaks & dic & rings & \\
\hline Untreated control & 12.7 & 6 & 1 & 3 & 0 & 0 & 2 & 0 & 6 \\
\hline DMSO & 13.9 & 4 & 0 & 1 & 1 & 0 & 3 & 0 & 5 \\
\hline Curcumin 2.5 & 13.4 & 7 & 2 & 4 & 1 & 0 & 0 & 0 & 7 \\
\hline 5 & 14.0 & 9 & 3 & 1 & 1 & 1 & 3 & 0 & 9 \\
\hline 10 & 10.6 & 12 & 1 & 2 & 2 & 1 & 4 & 1 & 11 \\
\hline BLM & 5.0 & 46 & 11 & 31 & 17 & 4 & 2 & 1 & 66 \\
\hline Curcumin $2.5+$ BLM & 5.9 & $75^{* *} *$ & 43 & 48 & 15 & 5 & 4 & 0 & $115^{*}$ \\
\hline $5+\mathrm{BLM}$ & 5.8 & $88 * *$ & 68 & 92 & 23 & 2 & 4 & 1 & $190 * *$ \\
\hline $10+B L M$ & $2.9^{*}$ & $125^{* *}$ & 78 & 223 & 28 & 18 & 6 & 1 & $354^{* *}$ \\
\hline
\end{tabular}

For symbols and abbreviations see Table I. *Statistically different when compared with untreated control **Statistically different when compared with BLM alone plus curcumin control. 
compounds (Cozzi et al., 1991; Musk et al., 1997). Several natural compounds and antioxidant agents, such as vanillin (Sasaki et al., 1987a,b, 1990), garlic acid (Knasmüller et al., 1989), humic acid (Cozzi et al., 1993), fatty acids (Sasaki et al., 1994), squalene (Fan et al., 1996) and Tochu tea (Nakamura et al., 1997), have shown antimutagenic properties against chromosomal damage in CHO cells.

As oxidative damage in biological systems is considered to cause aging, degenerative diseases and cancer, particular attention has been focused on the possibility of modulating these effects through the use of free-radical scavengers to minimize cellular injury. Curcumin is a natural antioxidant derived from turmeric, which has therapeutic properties and anticancer effects. These beneficial effects of turmeric have been postulated to be due to curcumin (Reddy and Lokesh, 1994).

In the present work, turmeric was not clastogenic by itself whereas curcumin increased both the number of abnormal metaphases and the frequency of chromosomal aberrations at the highest concentration in cells treated for 13 and $9 \mathrm{~h}$. As the cell cultures were treated with curcumin during 13, 9 and $4 \mathrm{~h}$, respectively for cells treated by BLM in $\mathrm{G}_{1} / \mathrm{S}, \mathrm{S}$ and $\mathrm{G}_{2} / \mathrm{S}$ phases, the curcumin-induced damage was higher in the 13-h treatment compared with the 9-h treatment, and was not statistically significant in the 4-h treatment compared with untreated controls (Tables IV, V and VI).

Turmeric was found to be non-mutagenic in mice and rats (Vijayalaxmi, 1980) and in the Ames test (Nagabhushan et al., 1987). However, it induced chromosomal damage in plant systems (Abraham et al., 1976) and was weakly clastogenic in acutely treated mice (Mukhopadhyay et al., 1998). Turmeric can also antagonize the mutagenicity of other substances (Shalini and Srinivas, 1990; Srinivas and Shalini, 1991; Mukundan et al., 1993). According to our results turmeric did not reduce the BLM-induced chromosomal aberrations; instead, it showed a slight tendency to increase the chromosomal damage induced by BLM at $\mathrm{G}_{1} / \mathrm{S}$ phase (Table I).

Some authors have noticed that curcumin is nonmutagenic in CHO cells (Au and Hsu, 1979), Ames test (Nagabhushan et al., 1987) and mice (Abraham et al., 1993). Nevertheless, our data clearly indicate that curcumin at 10 $\mu \mathrm{g} / \mathrm{ml}$ is clastogenic when present in the culture for more than $9 \mathrm{~h}$. Clastogenic effects of curcumin were also observed by others. Mukhopadhyay et al. (1998) reported a slight increase in the number of chromosomal aberrations in acutely treated mice by curcumin. Giri et al. (1990) observed a significant increase in SCE and a weak increase in the frequency of chromosomal aberrations in mice and rats treated acute and chronically with curcumin. Ishidate Jr. et al. (1984), using a Chinese hamster fibroblast cell line, noticed that curcumin was clastogenic at $30 \mu \mathrm{g} / \mathrm{ml}$. We have observed that curcumin is cytotoxic at concentrations higher than $20 \mu \mathrm{g} / \mathrm{ml}$ (data not shown).
Curcumin significantly reduced the frequencies of micronucleated polychromatic erythrocytes in mice exposed to $\gamma$-radiation (Abraham et al., 1993), and it was also indicated as an antimutagen against environmental mutagens in vitro and an antitumor drug in vivo (Nagabhushan et al., 1987; Nagabhushan and Bhide, 1992). However, curcumin and turmeric could not inhibit cyclophosphamide- or mitomycin-C-induced chromosomal aberrations in mice (Mukhopadhyay et al., 1998). According to our data, curcumin increased significantly the frequencies of both abnormal metaphases and chromosomal aberrations induced by BLM at $\mathrm{S}$ and $\mathrm{G}_{2} / \mathrm{S}$ phases when compared with BLM plus curcumin controls. The potentiating influence of curcumin on the clastogenicity of BLM was reproducible in three independent experiments. A potentiation effect with curcumin was also observed by Sahu and Washington (1992). They demonstrated the pro-oxidant properties of ascorbic acid and curcumin on quercetin-induced nuclear damage in presence of iron and copper. Therefore, according to these authors ascorbic acid and curcumin may have a dual role in carcinogenesis.

A potentiation effect of known antioxidant compounds combined with clastogenic compounds has also been reported by others. Chromosome aberrations induced by alkylating agents in cultured Chinese hamster cells were enhanced in the presence of $\sigma$-vanillin, an isomer of vanillin (Matsumura et al., 1993). Aruoma (1993) found a prooxidant action of vitamin $\mathrm{E}$ in an assay for DNA damage with BLM and iron. Anderson et al. (1994) showed that ascorbic acid produced exacerbating effects using Comet assay with human lymphocytes when it was combined with BLM. Cozzi et al. (1997) observed that ascorbic acid increased BLM-induced aberrations in $\mathrm{CHO}$ cells, whereas $\beta$-carotene had no effect on chromosomal aberrations induced by BLM. Conversely, Salvadori et al. (1994) observed that $\beta$-carotene enhanced the clastogenicity induced by BLM in CHO cells.

Since BLM is a radiomimetic compound, the effects of some radioprotectors on its genetic activity have been evaluated. Radioprotectors, such as DMSO, 2[(aminopropyl)amino] ethanethiol (WR-1065) (Hoffman et al., 1993) and cysteamine (Hoffman and Littlefield, 1995), potentiated the clastogenic activity of BLM in $G_{o}$ human lymphocytes. In contrast, WR-1065 has been reported to protect against the effects of BLM in cultured Chinese hamster cells (Nagy and Grdina, 1986).

BLM acts by generating oxygen radical species and it can be destroyed by the reactive oxygen species produced by itself (Scheulen et al., 1981; Lopez-Larraza et al., 1990). Salvadori et al. (1994) suggested that the presence of a scavenger, such as ascorbic acid and $\beta$-carotene, could cancel or reduce this detoxification. As curcumin is also a free-radical scavenger (Kunchandy and Rao, 1990), a similar mechanism may explain the potentiating effect observed. However, we have observed that curcumin also enhances $\gamma$-radiation-induced chromosomal aberrations in 
CHO cells (Araújo et al., 1999), and since curcumin was clastogenic by itself, another mechanism could be involved.

Chromosomal aberrations are believed to result from unrepaired and misrepaired DNA lesions, and inhibitors of DNA repair can induce an enhancement of the DNA damage caused by many kinds of compounds (Kihlman and Natarajan, 1984; Noviello et al., 1994). Curcumin increased the BLM-induced chromosomal damage at $\mathrm{S}$ and $\mathrm{G}_{2} / \mathrm{S}$ phases, but not in $\mathrm{G}_{1} / \mathrm{S}$. These data suggest that curcumin could inhibit a repair mechanism operating during $\mathrm{S}$ and $\mathrm{G}_{2} / \mathrm{S}$ phases in $\mathrm{CHO}$ cells.

Kuo et al. (1996) have noticed that curcumin induces apoptotic cell death in promyelocytic leukemia HL60 cells through free-radical generation. Although the exact mechanism by which curcumin induces reactive oxygen species remains to be elucidated, Kunchandy and Rao (1990) reported the ability of curcumin at low concentrations to generate hydroxyl radical through the Fenton reaction by reducing $\mathrm{Fe}^{3+}$ to $\mathrm{Fe}^{2+}$, as well as possessing scavenging properties at higher levels. On the other hand, it has been postulated that BLM interacts with molecular oxygen and $\mathrm{Fe}^{2+}$ to produce superoxide anion and other oxygen metabolites (Sausville et al., 1978).

Potentiation of BLM by curcumin could also depend on its pro-oxidant activity. According to Sahu and Washington (1992), the antioxidant curcumin, like ascorbic acid, can become a pro-oxidant agent depending on the redox state of the biological environment. Therefore, the clastogenic and potentiating effects of curcumin found in the present work could be explained by the fact that curcumin would act as a pro-oxidant agent at the highest concentrations tested under the conditions of the present report. Possibly, in other conditions curcumin acts as an antioxidant agent.

On the basis of these data, we may conclude that turmeric and curcumin did not protect against BLM-induced chromosomal aberrations; conversely, curcumin exhibited a clastogenic and potentiating effect. However, the mechanism by which curcumin acts remains to be investigated, and further studies are necessary to clarify this point.

\section{ACKNOWLEDGMENTS}

The authors thank Ana Maria R. Romero for preparing bleomycin, and Mr. Luiz A. Costa Jr. and Miss Sueli A. Neves for technical assistance. This investigation was supported by CAPES, FAPESP and CNPq. Publication supported by FAPESP.

\section{RESUMO}

Antioxidantes de ocorrência natural têm sido exaustivamente estudados quanto a sua capacidade de proteger organimos e células contra danos oxidativos. Muitos constituintes das plantas, incluindo cúrcuma e curcumina, parecem ser potentes antimutágenos e antioxidantes. Os efeitos de cúrcuma e curcumina na freqüência de aberrações cromossômicas induzidas pelo agente radiomimético bleomicina (BLM) foram investigados em células do ovário de hamster chinês (CHO). Três concentrações de cada droga, cúrcuma (100, 250 e $500 \mu \mathrm{g} / \mathrm{ml})$ e curcumina $(2,5,5,0$ e $10 \mu \mathrm{g} / \mathrm{ml})$, foram combinadas com BLM $(10 \mu \mathrm{g} / \mathrm{ml})$ em células CHO tratadas durante as fases $\mathrm{G}_{1} / \mathrm{S}, \mathrm{S}$ ou $\mathrm{G}_{2} / \mathrm{S}$ do ciclo celular. Nem cúrcuma nem curcumina evitaram o dano cromossômico induzido pela BLM em fase alguma do ciclo celular. Ao contrário, a potenciação da clastogenicidade da BLM pelo curcumina foi nitidamente observada em células tratadas durante as fases $\mathrm{S}$ e $\mathrm{G}_{2} / \mathrm{S}$. A curcumina também se mostrou clastogênica na dose de $10 \mu \mathrm{g} / \mathrm{ml}$ nos protocolos de tratamento de 9 e $13 \mathrm{~h}$. Contudo, o mecanismo exato pelo qual a curcumina produziu efeitos potenciadores e clastogênicos permanece desconhecido.

\section{REFERENCES}

Abraham, S., Abraham, S.K. and Radhamony, G. (1976). Mutagenic potential of the condiments, ginger and turmeric. Cytologia 41: 591-595.

Abraham, S.K., Sarma, L. and Kesavan, P.C. (1993). Protective effects of chlorogenic acid, curcumin and $\beta$-carotene against $\gamma$-radiationinduced in vivo chromosomal damage. Mutat. Res. 303: 109-112.

Ammon, H.P.T. and Wahl, M.A. (1991). Pharmacology of Curcuma longa. Planta Med. 57: 1-7.

Anderson, D., Yu, T.-W., Phillips, B.J. and Schmezer, P. (1994). The effect of various antioxidants and other modifying agents on oxygenradical-generated DNA damage in human lymphocytes in the COMET assay. Mutat. Res. 307: 261-271.

Anto, R.J., George, J., Babu, K.V.D., Rajasekharan, K.N. and Kuttan, R. (1996). Antimutagenic and anticarcinogenic activity of natural and synthetic curcuminoids. Mutat. Res. 370: 127-131.

Araújo, M.C.P., Dias, F.L. and Takahashi, C.S. (1999). Potentiation by turmeric and curcumin of $\gamma$-radiation-induced chromosome aberrations in Chinese hamster ovary cell. Teratog. Carcinog. Mutagen. 19: 9-18.

Aruoma, O.I. (1993). Use of DNA damage as a measure of prooxidant actions of antioxidant food additives and nutrient compounds. In: DNA and Free Radicals (Halliwell, B. and Aruoma, O.I., eds.). Ellis Horwood Ltd., London, pp. 315-327.

Au, W. and Hsu, T.C. (1979). Studies on the clastogenic effects of biological stains and dyes. Environ. Mutagen. 1: 27-35.

Cozzi, R., Perticone, P., Bona, R. and Polani, S. (1991). Antimutagenic activities of naturally occurring polyamines in Chinese hamster ovary cells in vitro. Environ. Mol. Mutagen. 18: 207-211.

Cozzi, R., Nicolai, M., Perticone, P., De Salvia, R. and Spuntarelli, F. (1993). Desmutagenic activity of natural humic acids: inhibition of mitomycin C and maleic hydrazide mutagenicity. Mutat. Res. 299: 37-44.

Cozzi, R., Ricordy, R., Agliti, T., Gatta, V., Perticone, P. and De Salvia, R. (1997). Ascorbic acid and $\beta$-carotene as modulators of oxidative damage. Carcinogenesis 18: 223-228.

Cunningham, M.L., Ringrose, P.S. and Lokesh, B.R. (1984). Inhibition of the genotoxicity of bleomycin by superoxide dismutase. Mutat. Res. 135: 199-202.

Fan, S.-R., Ho, I.-C., Yeoh, F.L.-F., Lin, C.-J. and Lee T.-C. (1996). Squalene inhibits sodium arsenite-induced sister chromatid exchanges and micronuclei in Chinese hamster ovary-K1 cells. Mutat. Res. 368: 165-169.

Giri, A.K., Das, S.K., Talukder, G. and Sharma, A. (1990). Sister-chromatid exchange and chromosome aberrations induced by curcumin and tartrazine on mammalian cells in vivo. Cytobios 62: 111-118.

Halliwell, B. (1994). Free radicals and antioxidants: a personal view. Nutr. Res. 52: 253-265.

Hoffman, G.R. and Littlefield, L.G. (1995). Enhancement of the activity of bleomycin by cysteamine in a micronucleus assay in Go human lymphocytes. Toxicol. Lett. 78: 147-151.

Hoffman, G.R., Coley, S.P. and Littlefield, L.G. (1993). Induction of micronuclei by bleomycin in Go human lymphocytes: II. Potentiation by radioprotectors. Environ. Mol. Mutagen. 21: 136-143. 
Ishidate Jr., M., Sofuni, T., Yoshikawa, K., Hayashi, M., Nohmi, T., Sawada, M. and Matsuoka, M. (1984). Primary mutagenicity screening of food additives currently used in Japan. Food Chem. Toxicol. 22: 623-636.

Kada, T., Inoue, T., Ohta, T. and Shirasu, Y. (1986). Antimutagens and their modes of action. In: Antimutagenesis and Anticarcinogenesis Mechanisms (Bronzetti, G., Hayatsu, H., De Flora, S., Waters, M.D. and Shankel, D.M., eds.). Plenum, New York, pp. 181-196.

Kihlman, B.A. and Natarajan, A.T. (1984). Potentiation of chromosomal alterations by inhibitors of DNA repair. In: DNA Repair and its Inhibition (Collins, A., Dowens, C.S. and Johson, R.T., eds.). IRL, Oxford, pp. 319-339.

Knasmüller, S., Martin, R., Dmjan, G. and Szakmary, A. (1989). Studies on the antimutagenic activities of garlic extract. Environ. Mol. Mutagen. 13: 357-365.

Kunchandy, E. and Rao, M.N.A. (1990). Oxygen radical scavenging activity of curcumin. Int. J. Pharm. 58: 237-240.

Kuo, M.-L., Huang, T.-S. and Lin, J.-K. (1996). Curcumin, an antioxidant and antitumor promoter, induces apoptosis in human leukemia cells. Biochim. Biophys. Acta 1317: 95-100.

Lopez-Larraza, D., De Luca, J.C. and Bianchi, N. (1990). The kinetics of DNA damage by bleomycin in mammalian cells. Mutat. Res. 232: 57-61.

Lown, W.J. and Sim, S.K. (1977). The mechanism of the bleomycin-induced cleavage of DNA. Biochem. Biophys. Res. Comm. 77: 1150-1157.

Matsumura, H., Watanabe, K. and Ohta, T. (1993). $\sigma$-Vanillin enhances chromosome aberrations induced by alkylating agents in cultured Chinese hamster cells. Mutat. Res. 298: 163-168.

Moorhead, P.S., Nowell, P.C., Mellman, W.J., Batipps, D.M. and Hungerford, D.A. (1960). Chromosome preparation of leukocytes cultured from human peripheral blood. Exp. Cell Res. 20: 613-616.

Mukhopadhyay, M.J., Saha, A. and Mukherjee, A. (1998). Studies on the anticlastogenic effect of turmeric and curcumin on cyclophosphamide and mitomycin C in vivo. Food Chem. Toxicol. 36: 73-76.

Mukundan, M.A., Chacko, M.C., Annapurna, U.V. and Krishnaswamy, K. (1993). Effect of turmeric and curcumin on BP-DNA adducts. Carcinogenesis 14: 493-496.

Musk, S.R.R., Clapham, P. and Johnson, I.T. (1997). Cytotoxicity and genotoxicity of diallyl sulfide and diallyl disulfide towards Chinese hamster ovary cells. Food Chem. Toxicol. 35: 379-385.

Nagabhushan, M. and Bhide, S.V. (1992). Curcumin as an inhibitor of cancer. J. Am. Coll. Nutr. 11: 192-198.

Nagabhushan, M., Amonkar, A.J. and Bhide, S.V. (1987). In vitro antimutagenicity of curcumin against environmental mutagens. Food Chem. Toxicol. 25: 545-547.

Nagy, B. and Grdina, D.J. (1986). Protective effects of 2-[(aminopropyl)amino] ethanethiol against bleomycin and nitrogen mustard-induced mutagenicity in V79 cells. Int. J. Rad. Biol. Phys. 12: 1475-1478.

Nakamura, T., Nakazawa, Y., Onizuka, S., Satoh, S., Chiba, A., Sekihashi, K., Miura, A., Yasugahira, N. and Sasaki, Y.F. (1997). Antimutagenicity of Tochu tea (an aqueous extract of Eucommia ulmoides leaves): 1 . The clastogen-suppressing effects of Tochu tea in $\mathrm{CHO}$ cells and mice. Mutat. Res. 388: 7-20.

Noviello, E., Alvigi, M., Cimoli, G., Rovini, E., Mazzoni, A., Parodi, S., De Sessa, F. and Russo, P. (1994). Sister chromatid exchange, chromosome aberrations and cytotoxicity produced by topoisomerase II targeted drugs in sensitive (A2780) and resistant (A2780-DX3) human ovarian cancer cells: correlations with the formation of DNA double-strand breaks. Mutat. Res. 311: 21-29.

Polasa, K., Sesikaran, B., Krishna, T.P. and Krishnaswamy, K. (1991). Turmeric (Curcuma longa) induced reduction in urinary mutagens. Food Chem. Toxicol. 29: 699-706.

Polasa, K., Ragahuram, T.C., Krishna, T. and Krishnaswamy, K. (1992). Effect of turmeric on urinary mutagens in smokers. Mutagenesis 7 :
107-109.

Povirk, L.F. and Austin, M.J.F. (1991). Genotoxicity of bleomycin. Mutat. Res. 257: 127-143.

Preston, R.J., Au, W., Bender, M.A., Brewen, J.G., Carrano, A.V., Heddle, J.A., Mcfee, A.F., Wolff, S. and Wasson, J.S. (1981). Mammalian in vivo and in vitro cytogenetic assays, a report of the EPA's Gene-Tox Program. Mutat. Res. 87: 143-188.

Preston, R.J., San Sebastian, J.R. and McFee, A.F. (1987). The in vitro human lymphocyte assay for assessing the clastogenicity of chemical agents. Mutat. Res. 189: 175-183.

Rao, C.V., Abraham, R., Simi, B. and Reddy, B.S. (1995). Chemoprevention of colon carcinogenesis by dietary curcumin, a naturally occurring plant phenolic compound. Cancer Res. 55: 259-266.

Reddy, A.C.P. and Lokesh, B.R. (1994). Effect of dietary turmeric (Curcuma longa) on iron-induced lipid peroxidation in the rat liver. Food Chem. Toxicol. 32: 279-283.

Sahu, S.C. and Washington, M.C. (1992). Effect of ascorbic acid and curcumin on quercetin-induced nuclear DNA damage, lipid peroxidation and protein degradation. Cancer Lett. 63: 237-241.

Salvadori, D.M.F., Ribeiro, L.R. and Natarajan, A.T. (1994). Effect of $\beta$ carotene on clastogenic effects of mitomycin $\mathrm{C}$, methyl methanesulphonate and bleomycin in Chinese hamster ovary cells. Mutagenesis 9: 53-57.

Sasaki, Y.F., Imanishi, H., Ohta, T. and Shirasu, Y. (1987a). Effects of antimutagenic flavourings on SCEs induced by chemical mutagen in cultured Chinese hamster cells. Mutat. Res. 189: 313-318.

Sasaki, Y.F., Imanishi, H., Ohta, T. and Shirasu, Y. (1987b). Effects of vanillin on sister chromatid exchanges and chromosome aberrations induced by mitomycin $\mathrm{C}$ in cultured Chinese hamster ovary cells. Mutat. Res. 191: 193-200.

Sasaki, Y.F., Imanishi, H., Watanabe, M., Ohta, T. and Shirasu, Y. (1990) Suppressing effect of antimutagenic flavorings on chromosome aberrations induced by UV-light or X-rays in cultured Chinese hamster cells. Mutat. Res. 229: 1-10.

Sasaki, Y.F., Sakaguchi, M., Yamagishi, T., Yamada, H. and Shirasu, Y. (1994). Bio-anticlastogenic effects of unsaturated fatty acids included in fish oil - docosahexaenoic acid, docosapentaenoic acid, and eicosapentaenoic acid - in cultured Chinese hamster cells. Mutat. Res. 320: 9-22.

Sausville, E.A., Peisach, J. and Horwitz, S.B. (1978). Effect of chelating agents and metal ions on the degradation of DNA by bleomycin and iron(II). Biochemistry 17: 2746-2754.

Scheulen, M.E., Kappus, H., Thyssen, D. and Schmidt, C.G. (1981). Redox cycling of Fe(III)-bleomycin by NADPH-cytochrome P-450 reductase. Biochem. Pharmacol. 30: 3385-3388.

Shalini, V.K. and Srinivas, L. (1990). Fuel smoke condensate induced DNA damage in human lymphocytes and protection by turmeric (Curcuma longa). Mol. Cell. Biochem. 95: 21-30.

Sharma, O.P. (1976). Antioxidant activity of curcumin and related compounds. Biochem. Pharmacol. 25: 1811-1812.

Sikic, B.I. (1986). Biochemical and cellular determinants of bleomycin cytotoxicity. Cancer Surv. 5: 81-91.

Srimal, R.C. and Dhawan, B.N. (1973). Pharmacology of diferuloylmethane (curcumin) a non-steroidal anti-inflammatory agent. J. Pharm. Pharmacol. 25: 447-451.

Srinivas, L. and Shalini, V.K. (1991). DNA damage by smoke: protection by turmeric and other inhibitors of ROS. Free Radic. Biol. Med. 11: 277-283.

Srivastava, R., Dikshit, M., Srimal, R.C. and Dhawan, B.N. (1985). Antithrombotic effect of curcumin. Thromb. Res. 40: 413-417.

Vijayalaxmi (1980). Genetic effects of turmeric and curcumin in mice and rats. Mutat. Res. 79: 125-132.

(Received January 6, 1998) 
